\title{
Security of growing habits and bud formation of German sour cherry varieties
}

\author{
Franjo ${ }^{1}$, D., Szőke', S., Nyéki ${ }^{1}$, J. \& Hilsendegen² ${ }^{2}$ P. \\ ${ }^{1}$ University of Debrecen Centre for Agricultural and Applied Economic Sciences, \\ H-4032 Debrecen, Böszörményi str. 138., Hungary \\ ${ }^{2}$ Rheinland-Pfalz Research Station Oppenheim, Germany
}

\begin{abstract}
Summary: Intensive sour cherry production is concerned to find the most productive varieties under special growing conditions. High planting density, adapted to manual picking or on the other hand to mechanical harvesting. Almost as important is the prolongation of the ripening season by enlarging the choice of varieties. Unfortunately, three of our four leading commercial varieties are ripe almost at the same date. Therefore, new varieties ought to be examined thoroughly. In the Pallag Experimental Station of the Debrecen University, five European varieties have been grown ('Schattenmorelle', 'PI-SA 12,100', 'Jade', 'Gerema', 'Achat') and a Hungarian one, 'Debreceni bötermö' used as a check for the experiments to compare their growing and yielding habits in 2010. The plantation was three years old, standing on Prunus mahaleb rootstocks, in high density $(5 \times 2 \mathrm{~m})$ and trained to slender spindle crowns. The results are proving that some of the varieties in question are suitable to prolong the harvesting season.

Growing habits and yields of the varieties related to the variety 'Debreceni bötermö' were similar or even better as 'Jade', 'Gerema' and 'Achat'. The 'Jade' excelled with its vitality and 'Gerema' with its generative character. Further studies are expected to prove the utility of one of them at least to enlarge the ripening season on the fruit market.
\end{abstract}

Key words: sour cherry varieties, shoot length, growing habits, flower bud formation

\section{Introduction}

The prolongation of the harvesting season on the sour cherry market is a permanent question of growers. High productivity and suitability for intense growing technologies are leading criteria to be observed. High density of planting and alternatively, manual or mechanical harvest are the main properties of a modern technology. Another important purpose of searching for new varieties is the enlarged harvesting season.

Among the vegetative properties of varieties are the relative growing vitality, tendency of ramification, size and form of the crown, response to training for slender spindle in a dense planting system. In addition to that, we need the parameters of the frequency of fruiting structures, the dynamics of forming flower buds and setting fruits. Jointly, observations are needed to be able to predict yields and the distribution of fruit load on the tree crown.

According to Apostol (2003), explains that the main purposes of sour cherry breeding are high yields, self- or mutual compatibility with each other and are representing a broad scale of ripening dates, moreover, their fruit is suitable for all types of utilisation (fresh consumption or processing), tolerate intensive as well as extensive growing conditions, which means also resistance or field-tolerance to pathogens and pests (Holb, 2004).

At the same time, Soltész (2004) is setting forth that the method of finding better varieties for fresh consumption one has to select from the rich regional populations of sour cherries, or make purposeful crosses between selected trees of local or acclimatised alien accessions. Special attention should be paid to suitability or ease of manual harvesting under intensive growing technologies

In Hungary at present, 'Érdi bőtermö' and the local accessions of the north eastern part of the country dominate the assortment of sour cherry varieties, which means also the main problem as for their relatively synchronous maturity dates. It causes difficulties in harvesting and sales on the domestic as well as on the foreign markets (Szabó et al., 2008).

\section{Materials and methods}

In spring of 2010, samples have been selected randomly in the plantation. Each sample was a one year old primary branch with 10 replications per variety. Data have been collected on those samples.

Parameters to be noticed:

- length of shoots $\left(\mathrm{cm} / \mathrm{cm}^{2}\right)$

- total sum of buds (piece/m, piece/ $/ \mathrm{cm}^{2}$ ),

- number of bouquets of flower buds on spears (piece/ $/ \mathrm{cm}^{2}$ ) and distribution (piece/m),

- number of flowers (piece $/ \mathrm{cm}^{2}$ ),

- rate of flowers per bouquets of flower buds (\%), 
Results have been specified by the cross section area of the respective branches where necessary. The purpose was to avoid biases effects due to heterogeneity of the samples.

The weather conditions of the locality are presented in Table 1.

Table 1. Local meteorological data of Pallag

\begin{tabular}{|l|c|}
\hline Yearly sum of temperatures & $3200-3300{ }^{\circ} \mathrm{C}$ \\
\hline Yearly sum of sunny hours & $2000 \mathrm{~h} /$ year \\
\hline Mean temperature per year & $9.99^{\circ} \mathrm{C}$ \\
\hline Frosty days per year & $100-110$ days/year \\
\hline Sum of precipitation & $500-550 \mathrm{~mm}$ \\
\hline
\end{tabular}

The soil of plantation was a sandy loam with the following parameters presented in Table 2.

Table 2. Parameters of the soil of Pallag Experimental Station

\begin{tabular}{|l|c|}
\hline $\mathrm{KA}$ & 27 \\
\hline $\mathrm{pH}$ & 5.6 \\
\hline $\mathrm{Humus} \%$ & 0.6 \\
\hline $\mathrm{NO}_{3}+\mathrm{NO}_{2} \mathrm{mg} / 1000 \mathrm{~g}$ & 17 \\
\hline $\mathrm{P}_{2} \mathrm{O}_{2} \mathrm{mg} / 1000 \mathrm{~g}$ & 48 \\
\hline $\mathrm{K}_{2} \mathrm{O} \mathrm{mg} / 1000 \mathrm{~g}$ & $91-92$ \\
\hline
\end{tabular}

Sour cherry trees are planted in 2008. All are grafted in Prunus mahaleb. The varieties observed are 'Schattenmorelle', 'PI-SA 12,100', 'Jade', 'Gerema' and 'Achat'. The variety 'Debreceni bötermö' served as check and was also a graft on Prunus mahaleb. Planting density was uniformly $5 \mathrm{x}$ $2 \mathrm{~m}$, which means 1000 trees/ha. Trees were trained to slender spindles, which are considered as best suited for manual harvesting.

\section{Results and discussion}

In Figure 1, the growth of the three-year-old trees is shown specified with the cross section area of the respective branch.

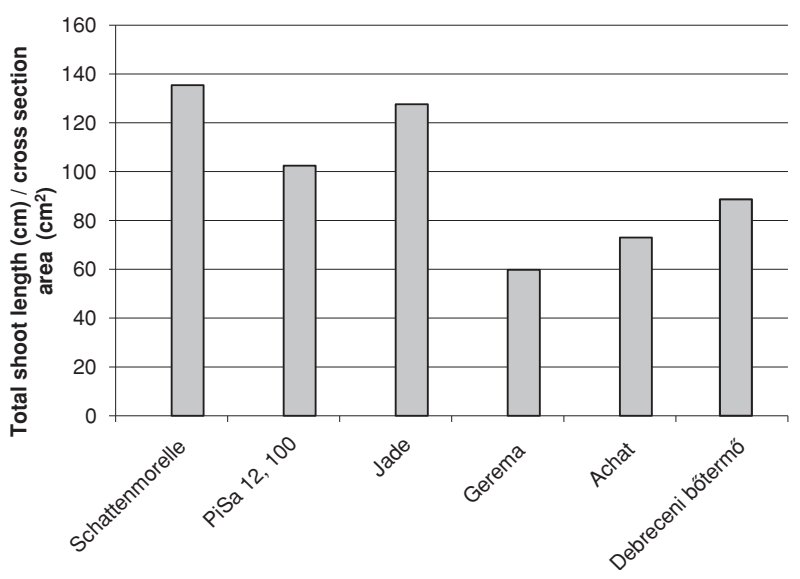

Figure 1. Shoot length specified by the cross section area of the respective branch (Debrecen-Pallag, 2010)
Those data indicate the growing vigour of the trees. 'Schattenmorelle', 'PiSa 12, 100' and 'Jade' are vigorously growing related to the three other varieties. Vigorous growth means that the plantation is more quickly exploited by young trees.

In Figure 2, the number of buds is related to the length of branches of different age of the tree.

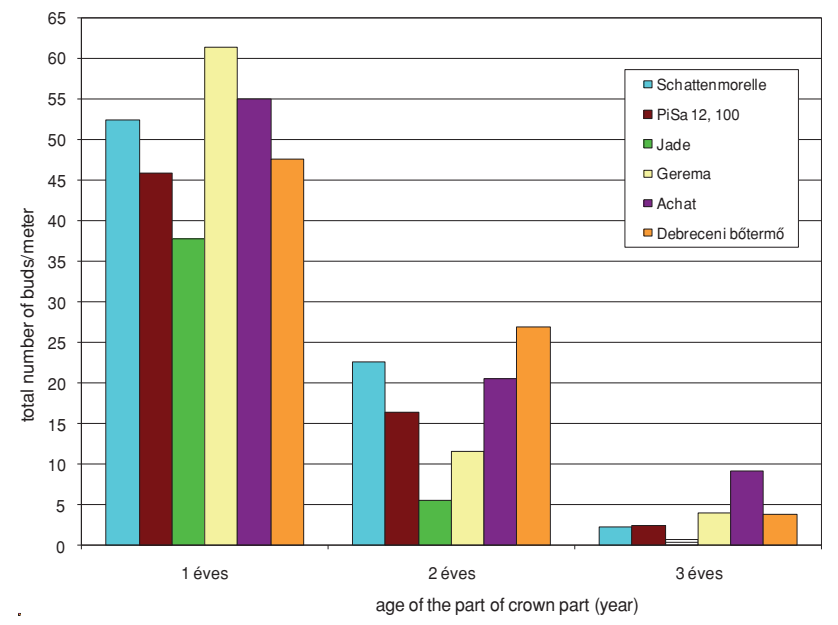

Figure 2. Number of buds grown on branches of different age on the trees (Debrecen-Pallag, 2010)

The number of buds grown on one, two and three year old crown parts was markedly different. The variety 'Jade' developed especially few buds on all the three type of branches. The variety 'Gerema' had many buds on the one year old parts, but no more on the two and three year old parts. 'Schattenmorelle' produced quite a few buds on all the three parts, which was followed by 'PiSa 12, 100' with almost the same intensity. 'Achat' was good in one and two year old parts and excelled markedly in the three year old parts. 'Debreceni bötermö', the check variety had good records in all the three age categories. In all cases, the number of buds diminished with the age of the branches.

In Figure 3, the sums of bouquets of flower buds in the varieties are presented as related to the cross section area of the respective branch.

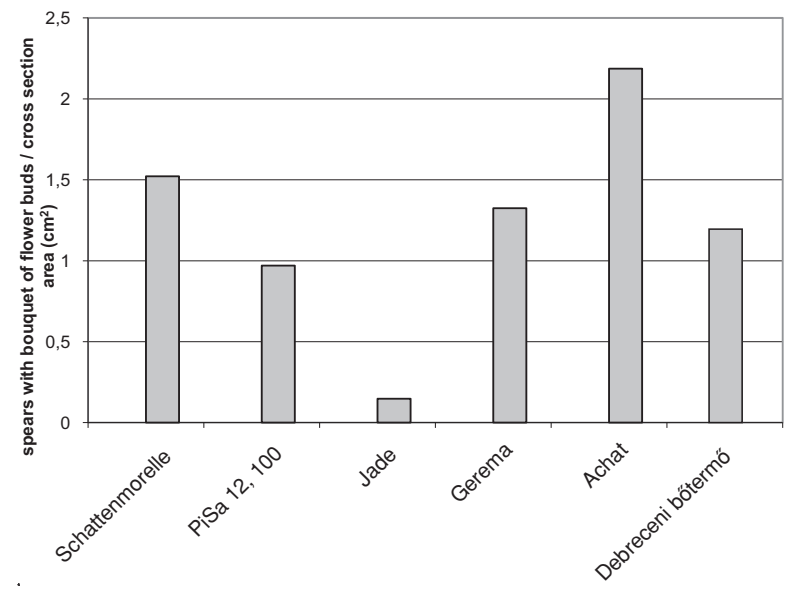

Figure 3. The number of bouquets of flower buds related to the cross section areas (Debrecen-Pallag, 2010) 
Evidently, 'Achat' developed the most bouquets and as a contrast, 'Jade' was the less active with very few bouquets. The rest of varieties equalled with the check variety.

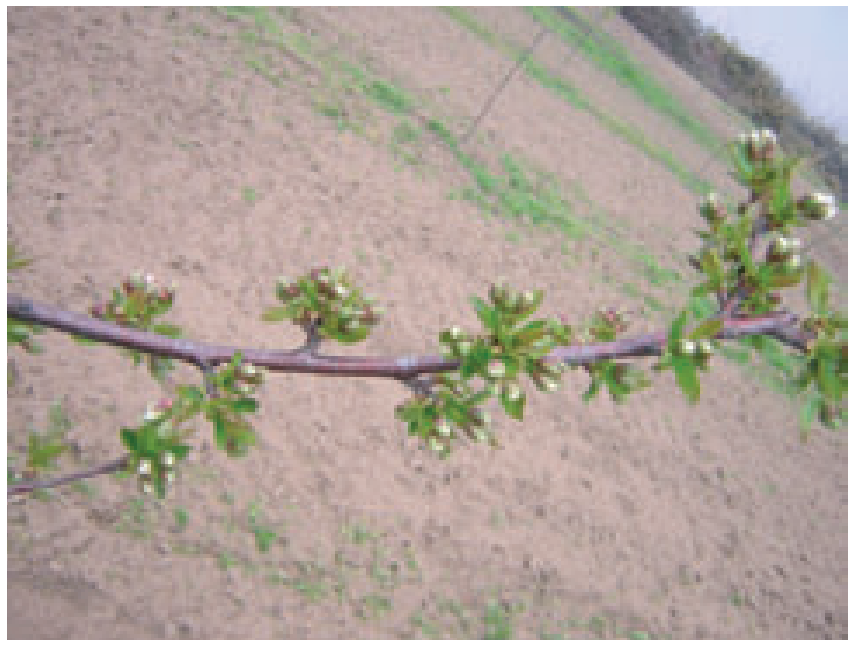

Figure 4. A branch of variety 'Achat' produceing many bouquets of flower buds (Debrecen-Pallag, 2010)

The number of flowers developed by the varieties is shown in Figure 5 specified by the cross section area.

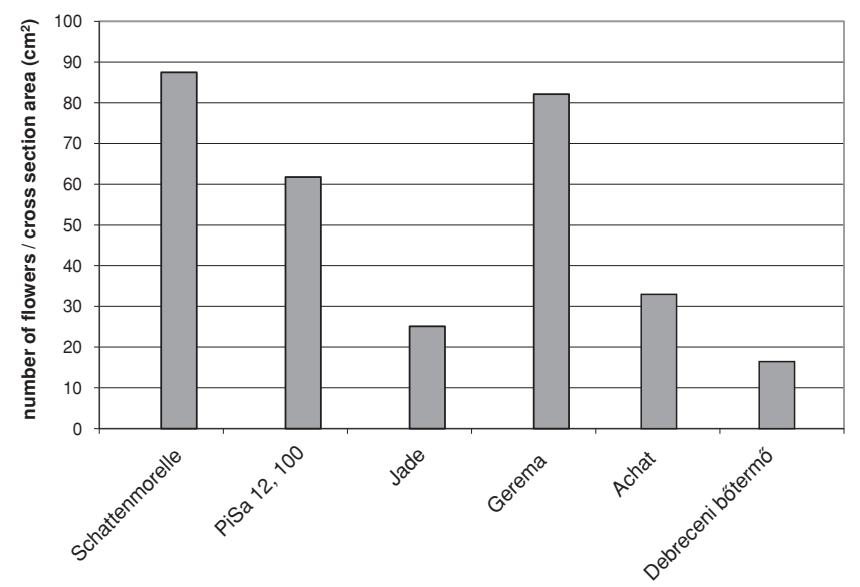

Figure 5. Specific number (related to cross section area) of flowers produced by sour cherry varieties (Debrecen-Pallag, 2010)

The total specific numbers of flowers per tree is widely variable according to varieties as visible on Figure 5. 'Schattenmorelle', 'PiSa 12,100' and 'Gerema' produced lot of flowers. The other three varieties bloomed much more sparsely, which may be interpreted as a delayed start of the fruiting period of the trees.

An important component of fruiting habits of the trees is the distribution of flowers within the crown as visualised by Figure 7.

As explained, on Figure 7, 'Achat' and 'Debreceni bötermö' developed about $50 \%$ of their flowers on the bouquets at the end of spears. The other four varieties have the majority of flowers on single buds developed on the shoots.

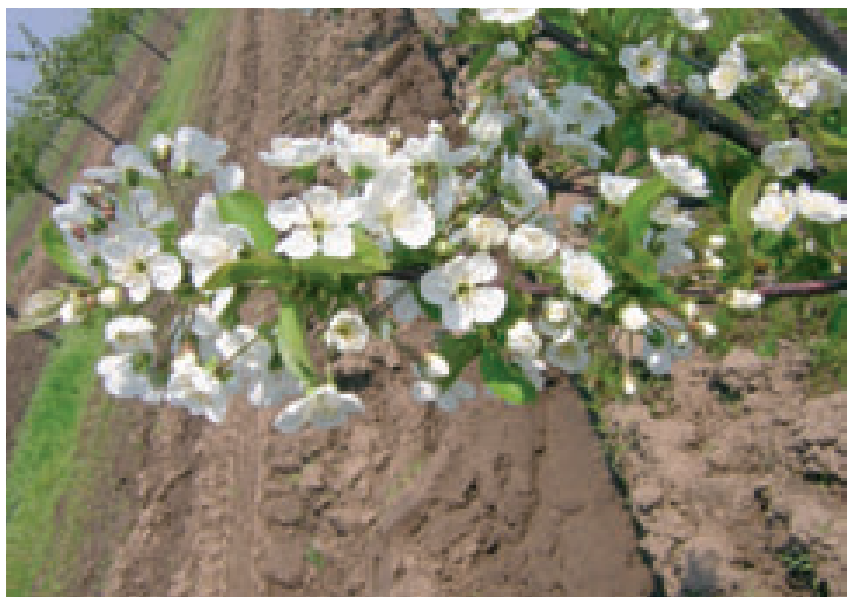

Figure 6. Profusely blooming branch of the variety 'Gerema' (DebrecenPallag, 2010)

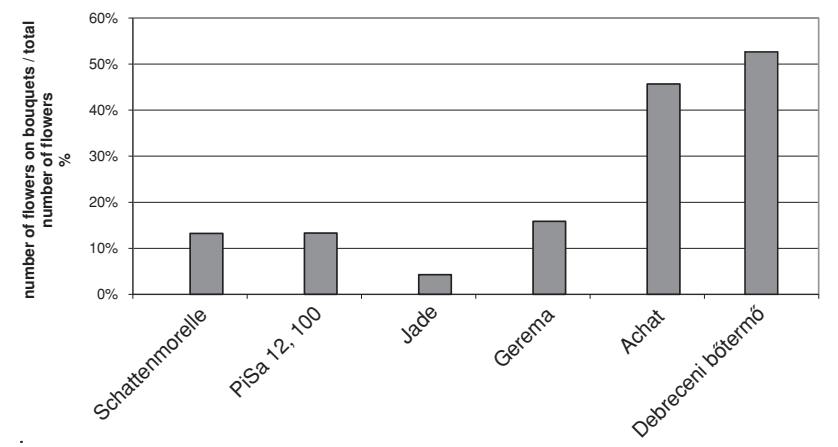

Figure 7. The ratio of flowers grown in bouquets shows marked differences between varieties (Debrecen-Pallag, 2010)

\section{Conclusions}

Evaluation of our results reveals important differences between the varieties examined. The variety 'Jade' grew vigorously and produced outstandingly few buds on the shoots, which is of concern if the tree should be trained to form a compact crown. Moreover, this variety bears fruit almost exclusively on the one year old shoots. Its opposite is 'Gerema', which is lagging in shoot length and profusely loaded with buds. Particularly outstanding with high rates of spears with bouquets of flower buds is the variety 'Achat'. It indicates its ease for manual harvesting. 'Pi-Sa 12, 100' and 'Schattenmorelle' represent good or medium values in our scrutiny, however, their other attributes (small fruit, tartish taste) would not be acceptable for fresh consumption. Other known properties as early decline of trees ought to be considered together carefully in choosing varieties to be grown for commercial purpose. Further investigations are also necessary because observations of a single season would be insufficient for final judgements. Preliminary results are precious for making decisions and finding further principles of orientation. So, the importance of early performance in new plantations is crucial, how it is recognised in growth and bud formation from the point of view of the beginning of fruiting period. 


\section{Aknowledgement}

Research was sponsored by NFÜ TECH_08-A3/2-20080373grant.

\section{References}

Apostol, J. (1998): Meggy. [In. Soltész M. (ed.): Gyümölcsfajtaismeret és -használat.] Mezőgazda Kiadó, Budapest, 288-307.

Apostol, J. (2003): Cseresznye- és meggynemesítés Magyarországon. [In. Hrotkó K. (ed.): Cseresznye és meggy.] Mezőgazda Kiadó, Budapest, p. 37.

Apostol, J. (2008): Cseresznye- és meggynemesítés szerepe és jelentősége a kertészeti termesztésben. Kertgazdaság, 40 (2): 15-20.

Brunner, T. (1990): Kis fákon nagy termés. Mezőgazdasági Kiadó, Budapest.

Brunner, T. (1991): A cseresznye és a meggy metszése, koronaalakítása. Mezőgazdasági Kiadó, Budapest.

G. Tóth M. (2001): Meggy. [In. G. Tóth M. (szerk.): Gyümölcsészet.] PRIMOM, Nyíregyháza, 268-287.
Gonda, I. (2010): Csonthéjas gyümölcsfák metszése. Debreceni Egyetem AMTC Kutatási és Fejlesztési Intézet Gonda István Betéti Társaság, Debrecen.

Holb, I.J. (2004): The brown rot fungi of fruit crops (Monilinia spp.): II. Important features of their epidemiology. INT J HORT SCI 10 (1): 17-33.

Inántsy, F. és Balázs, K. (szerk.) (2004): Integrált növénytermesztés: Meggy, cseresznye. Agroinform Kiadó, Budapest.

Schuster, M. (2007): Viel versprechend: die neuen Sauerkirschsorten. Obsbau, 6. 318-321

Soltész, M. (1997): Meggy. [In. Soltész M. (ed.): Integrált gyü mölcstermesztés.] Mezőgazda Kiadó, Budapest, 620-938.

Soltész, M. (2004): A meggytermesztés jelentősége, helyzete és környezeti feltételei. [In. Papp J. (szerk.): Gyümölcsök termesztése.] Mezőgazda Kiadó, Budapest, 296-298.

Szabó, T., Nyéki, J. \& Soltész, M. (2008): Magyarországi fajtahasználat. [In. Nyéki J., Soltész M., Szabó T. (ed.): Meggyültetvények létesítése és technológiája.] Debreceni Egyetem AMTC Kutatási és Fejlesztési Intézet, Debrecen, 16-20. 